\title{
Dynamics of Village Institution: the Gampong under Aceh's Special Autonomy
}

\author{
Irine Hiraswari Gayatri \\ Centre for Political Studies ${ }^{2}$ \\ Indonesian Institute of Sciences
}

\section{Introduction}

The paper is a résumé of a research project on the 'dynamics of [the] gampong institution under the Special Autonomy status in Aceh' that was conducted by a team from the Center for Political Studies (LIPI) in $2007 .^{3}$

Literature and media reports written for international and national fora consider that Indonesia is a country undergoing social and economic transformation. Social and political transformation takes place in the village, or nagari to use the Minangkabau term or kampong, the term used in Bener Meriah. The Acehnese use the term gampong, which also has sociological connotations. This study of the gampong was aimed at adding to the body of knowledge about social changes at the village level in Aceh, which traditional Acehnese call a gampong particularly in the context of law 11 of 2006, the Law on the Governance of Aceh (LOGA) after Aceh's peace settlement that was a result of the Helsinki Accord of 26 August 2005. In particular, this study looked at the dynamics of the gampong in Aceh as a social institution by understanding the changing context surrounding the gampong from time to time and it looked at

2 The team comprised Irine Hiraswari Gayatri, MA, Drs Heru Cahyono, Drs Afadlal, MA, Kurniawati Hastuti Dewi, MA, and Septi Satriani, S.Ip.

3 Undang-Undang Pemerintahan Aceh [Law on the Governance of Aceh (LOGA)] no. 11 of 2006, article 1, point 20, says that 'gampong or in other name is a unit of law-based society under mukim administrative territory which is lead by keuchik or other name which bears the rights to manage its own affairs'. 
how those shaped the current realities of the gampong. This study put the gampong in the context of democratisation in Indonesia and in the 2006 LOGA articles.

The study looked at the dynamics or changes of the gampong in Aceh from historical times to the present. The research used qualitative methods, which can be interpreted as 'any social science research that produces results that are not obtained by statistical procedures or other methods of quantification' (Bouma and Atkinson, 1995: 206). With this method, researchers are able to understand the social changes that surrounded and contextualised the existence of gampong in two locations of the field research, that is, North Aceh and Bener Meriah Districts. The study employs four main elements of the qualitative method: interview; participant observation; document and literature analysis; and focus-group discussions.

The researchers in the field used in-depth interviews and focus-group discussions to gather data. There were semi-structured interviews with over thirty (30) respondents from North Aceh and Bener Meriah Districts. Researchers lived in two places: Gampong Meriah of Matang Kuli Sub-district in North Aceh District; and Kampong Ramung Jaya, Permata Sub-district of Bener Meriah District. Living in the abovementioned two districts allowed each researcher to spend approximately two weeks on site, which helped to generate understanding of the local circumstances that show the realities of social, economic practices as well as enabling researchers to 'grasp' insights to the ways of the Acehnese in their daily activities. Field research is also a useful tool that provides opportunities to observe how social changes have enveloped the dynamics of Aceh society in their perceived roles in the gampong. Direct interaction, as well as in-depth interviews with the informants in Bener Meriah and North Aceh districts, gave ample opportunities for the research team to obtain detailed, first-hand information from primary sources about intergroup relations, in particular in the gampong; on the organisational structure of the gampong; and on how social changes have influenced the form and dynamics of the gampong. This paper is in two parts: the first section is a description of the gampong from an 
historical perspective and its realities under different circumstance in the Indonesian context; the second section looks at the recent state of the gampong.

\section{Changing Narratives of the Gampong}

In the body of social studies about Indonesia, one aspect is the village, which has received attention from national as well as international scholars when observing its societal relations. Early studies clearly show that in its pre-modern state, Indonesia was known to have 'authentic' societal structure, which represented spatiality as well as autonomy in its social and economic practices. Studies of the village in Indonesia have grown enormously since the 1970s and have focused on many aspects, ranging from the interaction among villagers, institutional changes under modernisation, and recently there have been studies that have linked the democratisation in Indonesia with changes experienced by villages. The spatial and social-economic arrangement in the small geographical milieux is known as a village or desa, to use the popular term during the New Order period. There basically exist two perspectives in seeing the ontology of a village, first as a state creation and, second, as a village entity that formed naturally in a kinship-based society.

A village used to be called autonomous for its ability in governing social life and economic events in terms of production capacity and financing the needs of society. However, the degree of autonomy of a village also largely depends on the modes of production or economy of the village, and on the interaction between villages and supra-village institutions. Before the modern state (Indonesia) existed, villages used to be attributed with 'authentic' culture that represented traditional economic modes of production (that is, agricultural societies, fishing communities, etc.); and at the same time followed a set of traditions that served as a worldview and a guide for the interactions among its community members (Koentjaraningrat, 1984: 1-18; Sosialismanto, 2001: xiv-xv). Local communities in the villages, as described by Kuntjoroningrat above, existed not only in Java but also in Sumatra. 
Basically villages not only represent a geographical landscape but also represent sociological functions in it.

Villages as well as kingdoms are two forms of organisation that take society as the basic component (Sosialismanto, 2001: xxi). The colonial rule by the Dutch in Java and Sumatra during the early 18th century highly influenced the traditional society in villages, including Acehnese gampongs. Anthony Reid looks at Aceh history under the fierce competition between Dutch and British trade companies and observed that Aceh had endured various regimes prior to Dutch colonialism that helped in forming the Acehnese identity (Reid, 1969; Reid, 2005). In the context of the development of modern Indonesia, villages have come under a lot of pressure since the beginning of colonial period and under the former New Order regime. Villages in Indonesia from Aceh to Papua experienced massive uniformity with the implementation of law 5 of 1979 on village governance. The principles of the regulation define villages in Indonesia in a way that allows only an administrative interpretation, that is, they are considered to be 'a unit of governance under the supervision of sub-district office'. This definition neglects sociological aspects and village characteristics that differ from one province to another. The law was designed to maintain control of the villages, which were relegated to the lowest order of the state's governance system. Thus, with this law the New Order state was able to extend control over the community as a strategy to support the state's bureaucratic hierarchy. As a consequence village autonomy eventually vanished.

That New Order co-opted villages to ensure its economic and political stability, apparently emulating the way colonial Dutch administrations ruled their territories. It was perceived as a way to ensure strategic and financial benefits flowed to the colonial kingdom. During the New Order period, villages functioned as the foundation for massive human mobilisations during election campaigns and, as well, when support was necessary for state-dominated development projects. This in turn caused the village communities to lose their autonomy and become passive whenever the state or a giant investment project entered their 
areas. In such a politically repressive climate, village society had no way of airing grievances nor expressing collective decisions because traditional mechanisms or adat had atrophied or disappeared. Statesponsored organisations, Lembaga Ketahanan Masyarakat Desa (LKMD) and Ketahanan Masyarakat Desa (KMD) had been imposed. This gloomy state of affairs also took place in gampongs and kampongs in Aceh, which has had almost 30 years of armed conflict from 1976 to 2006.

\section{Current State of the Gampong}

Gampong, besides being an Acehnese term for a village, also is a term for a unit of territorial governance, the lowest in the hierarchy of the current regional governance structure in Aceh. In the traditional history of Aceh, gampong also meant 'the smallest unit of adat society in Aceh' (Djuned, 2006). Gampong is interpreted as 'a traditional Acehnese territoriality'. The term gampong is preferred in some geographical areas of the province of Nanggroe Aceh Darussalam, for example, Aceh Rayeuk, Banda Aceh, Aceh Barat, Aceh Jaya, Nagan Raya, Pidie, and North Aceh. The communities in highland regions, that is, in Bener Meriah, Central Aceh, Gayo Luwes, are more likely to use the term kampong (Hurgronje, 1996: 11). Besides representing geographical territoriality as well as a social entity, gampong is also interpreted as a unit of 'adat society with territoriality' (Syarif, 2005: 12). Historically, in Aceh the gampong was a settlement comprising mainly houses (family homes) called umah or rumoh and several centres of productive activity that supported the community's local economy; for example, paddy fields or blang; farms or lampoh or seunebok; open fields or padang; and forest or gle(e) (Syarif, 2005). In Aceh, in the period before national independence, the social and institutional structures of the gampong experienced changes. There were more changes after independence caused in part by a series of regional upsurges, which included the Darul Islam/Tentara Islam Indonesia (DI/TII) movement in Aceh (Reid, 2004: 309; Miller, 2004: 335). Gampong functions and roles weakened, especially when social changes in Indonesia after 
independence had disastrous effects in Aceh in the form of social and political instability. The situation caused gampong communities to be reluctant to take part in political activities, particularly with positions of leadership in the gampong structure. This period also witnessed a dramatic turn in public recognition of traditional leadership, that is, the keuchik or head of the gampong, that used to be highly supported by the influential uleebalangs or noblemen.

During the time of the New Order in Indonesia, state structures replaced local and traditional institutions including gampong in Aceh, which was positioned under the official hierarchy of bureaucratic institutions. Gampong in the traditional Aceh system used to be part of mukim territory, which under the New Order was reduced to being merely an administrative unit below the sub-district level. As these traditional functions of the gampong had weakened, they could not prevent the development projects that entered remote areas in North Aceh and in the Gayo highlands. The Gayo highlands, in the early 1980s, experienced massive growth in the numbers of state-sponsored concessions for forestry companies. ${ }^{4}$ Gampong communities became poorer and their political participation had been circumscribed earlier (Sulaiman, 2006: 125-126). However, although Indonesia's state structure in terms of village governance replaced traditional structures with modern ones, which were followed by more administrative functions, some social functions of the gampong were maintained. Nonetheless, the keuchik and other gampong members had no income from their seunebok or productive land, different from what had been the case in the past. Social recognition of their adat role also eventually diminished (Amin, 1988: 210). In this context, although a keuchik officially serves a five-

4 During the New Order regime all kinds of local and traditional institutions, for instance those that used to function as consultative agencies for the village governance were made uniform to make state control of society easier. Statebased local institutions, Lembaga Masyarakat Desa (LMD) or Village Community Councils were formed and replaced the consultative function of tuha peut, which in the traditional gampong used to serve as the consultative body. A tuha peut usually comprises the respected elders who have been entrusted by the community to discuss village or gampong matters. Under the New Order, LMDs worked together with village heads to support government programs. 
year term in office, there used to be a tendency or an expectation that a keuchik may hold the position as gampong chief for life, especially if there is no one to replace him. Recently after Reformasi, a keuchik is directly elected by the community, although in particular cases if no one is able to serve as keuchik then the sub-district head (kecamatan) works together with the gampong consultative body - or tuha peut that consists of the elderly in the village - and later appoints a new keuchik. From 1976 to 2002, gampong communities in coastal Aceh and in highland areas were trapped under the armed conflict that left gampong leadership crippled. After the tsunami hit Aceh in December 2004, the gampong experienced massive changes in demography and socialeconomic structure. Table 1 below describes the changes of gampong in Aceh from Sultanate period up to recent times. 


\begin{tabular}{|c|c|c|c|c|}
\hline \multirow{7}{*}{ 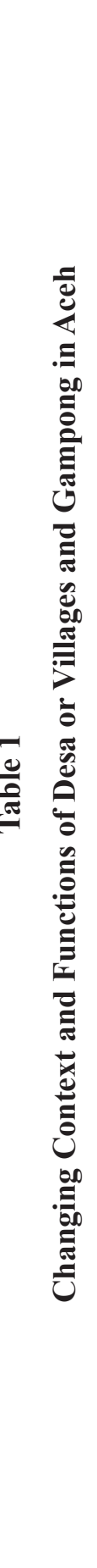 } & 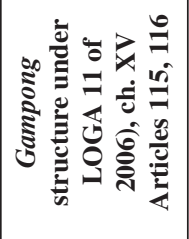 & 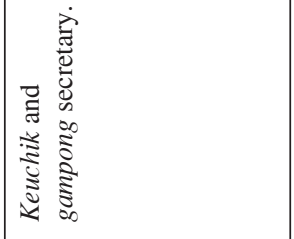 & 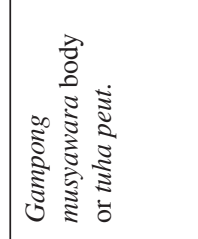 & 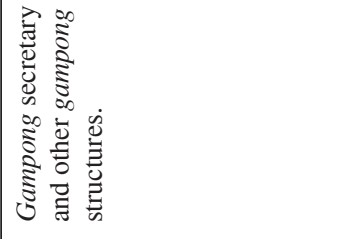 \\
\hline & 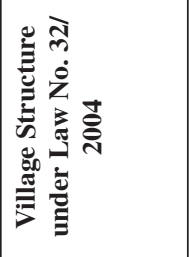 & 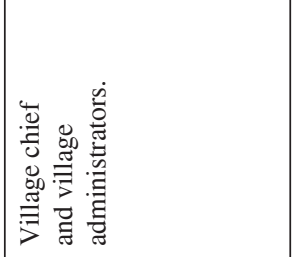 & 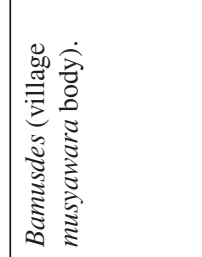 & 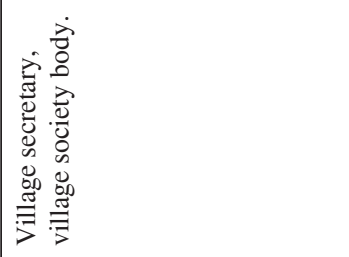 \\
\hline & 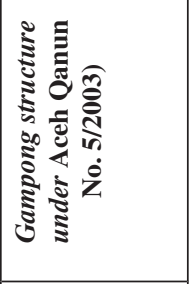 & 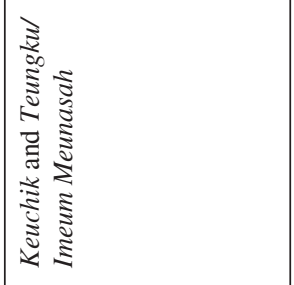 & 范 & 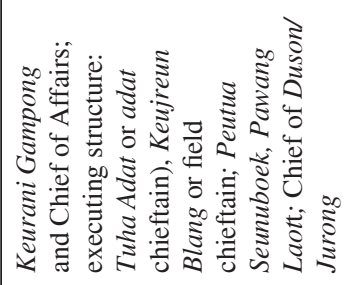 \\
\hline & 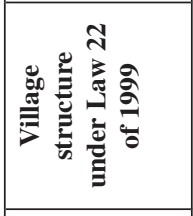 & 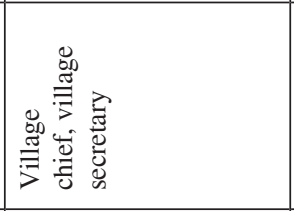 & 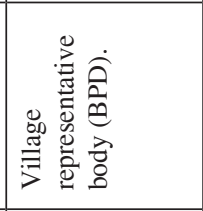 & 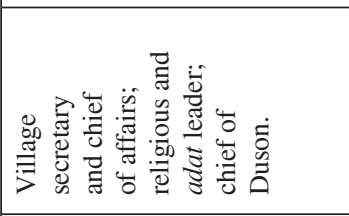 \\
\hline & 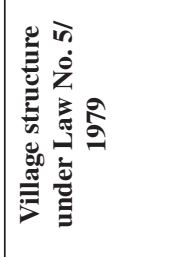 & 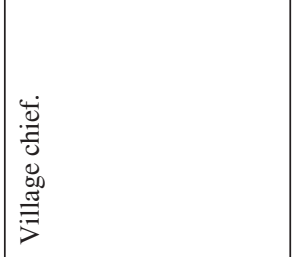 & 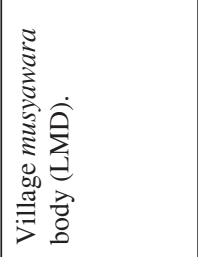 & 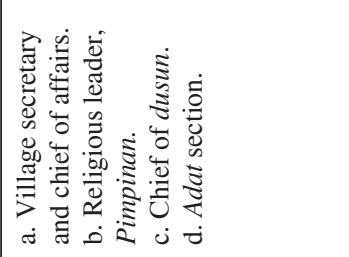 \\
\hline & 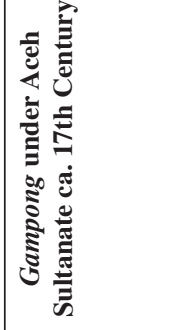 & 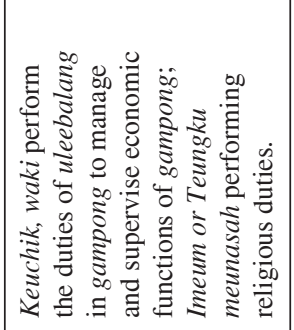 & 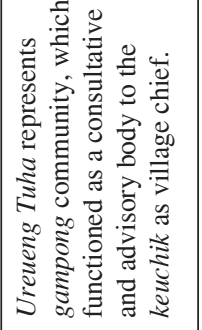 & 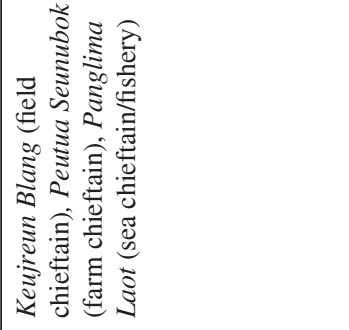 \\
\hline & 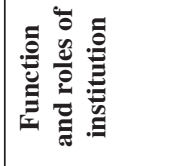 & 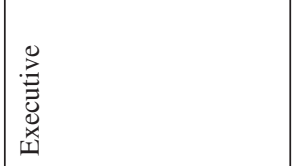 & 产 & 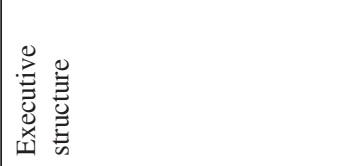 \\
\hline
\end{tabular}




\begin{tabular}{|c|c|c|}
\hline 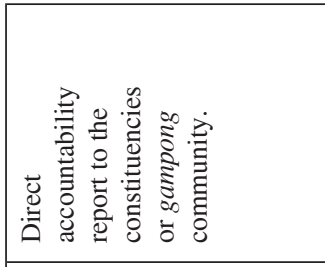 & 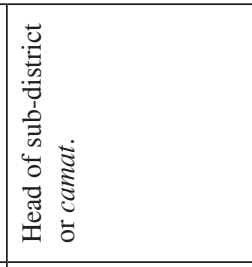 & 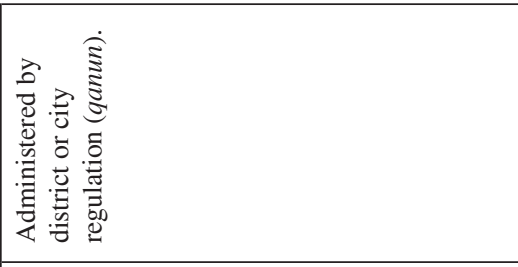 \\
\hline 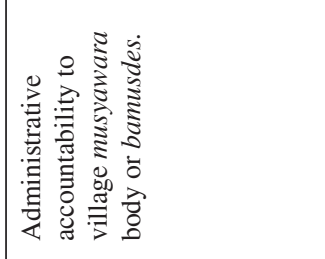 & 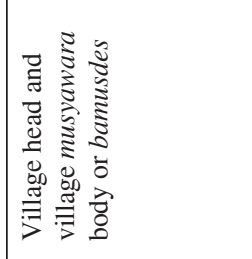 & 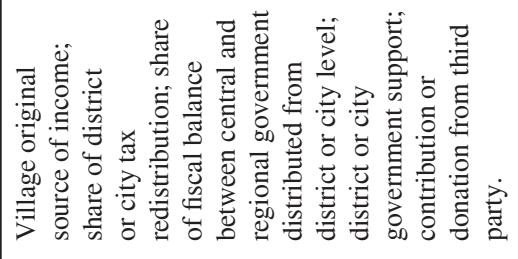 \\
\hline 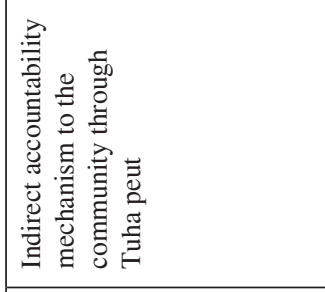 & 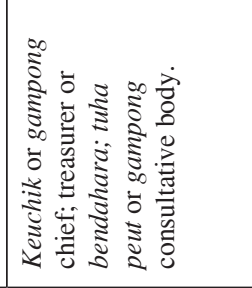 & 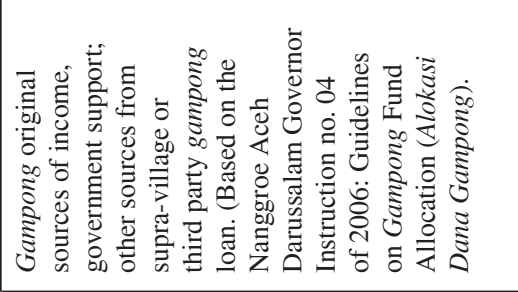 \\
\hline 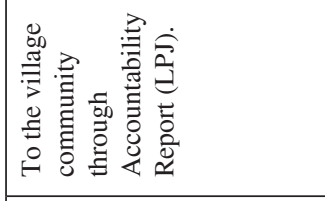 & 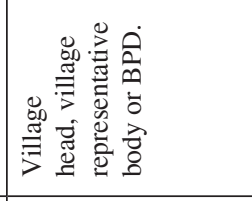 & 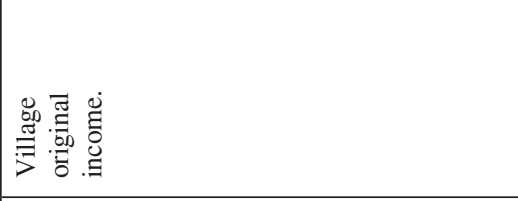 \\
\hline 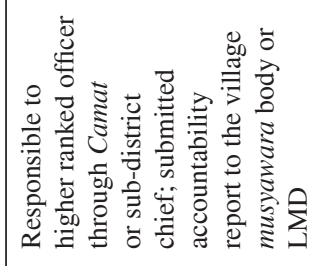 & 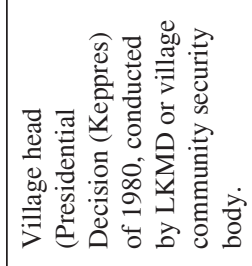 & 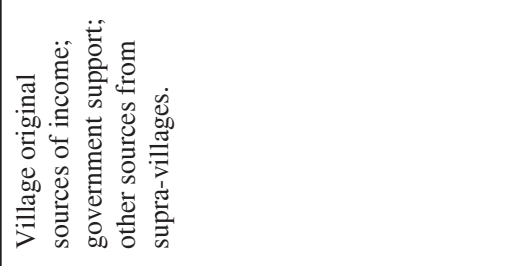 \\
\hline 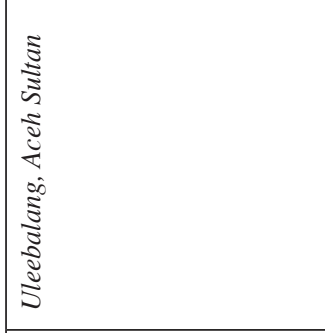 & & 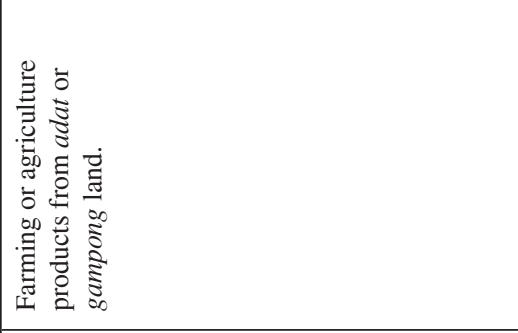 \\
\hline 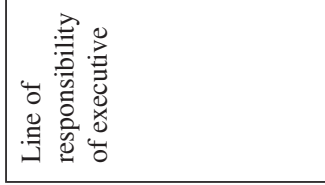 & 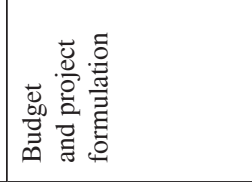 & 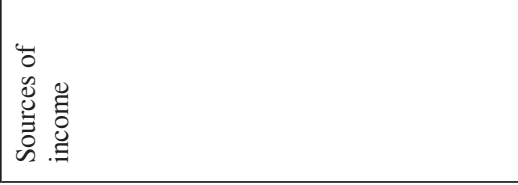 \\
\hline
\end{tabular}




\section{References}

\section{Books and Journals}

Amin, M Masyhur (1988). Kedudukan Kelompok Elite Aceh dalam Perspektif Sejarah. In Alfian, (pengantar) Kelompok Elit dan Hubungan Sosial di Pedesaan. Jakarta: Pustaka Grafika Kita.

Djuned, T (2006). Partisipasi Masyarakat dalam Mengelola Sumberdaya Alam. Unpublished article, Banda Aceh.

Hurgronje, C Snouck (1996). Aceh Rakyat dan Adat Istiadatnya. Jakarta: IndonesianNetherlands Cooperation in Islamic Studies.

Hurgronje, C Snouck (1996). Gayo Masyarakat dan Kebudayaannya. Jakarta: Balai Pustaka.

Koentjaraningrat (1984). Masyarakat Desa di Indonesia. Jakarta: Lembaga Penerbit Fakultas Ekonomi, Universitas Indonesia.

Miller, Michelle Anne (2004). The Nanggroe Aceh Darussalam Law: a Serious Response to Separatism? Asian Ethnicity, 5 (2) 335.

Reid, Anthony (1969). The Contest for North Sumatra: Atjeh, the Netherlands and Britain 1858-1898. London: Oxford University Press.

Reid, Anthony (2004). War, Peace and the Burden of History in Aceh. Asian Ethnicity, (5) 2, 309.

Reid, Anthony (2005). An Indonesian Frontier, Acehnese and Other Histories of Sumatra. Singapore: Singapore University Press.

Reid, Anthony (2006). Verandah of Violence, the Background of to the Aceh Problem. Singapore: Singapore University Press.

Sosialismanto, Duto (2001). Hegemoni negara: ekonomi politik pedesaan Jawa. Yogyakarta: Lapera Pustaka Utama.

Sulaiman, M Isa (2006). From Autonomy to Periphery: a Critical Evaluation of the Acehnese Nationalist Movement. In Anthony Reid, Verandah of Violence, op. cit.

Tripa, Sulaiman (2003). Rekonstruksi Gampong di Aceh. Retrieved from www. acehinstitute.org on 23 June 2007.

Undang-Undang Pemerintahan Aceh (UUPA) No. 11/2006. Jakarta: Sinar Grafika.

\section{Website}

Syarif, Sanusi M (2005). Gampong dan Mukim di Aceh: Menuju Rekonstruksi Paska Tsunami. Bogor: Pustaka Latin. 